\title{
Interorganisational Collaboration in View of the Theory of Entrepreneurship
}

\begin{abstract}
Rafat Kusa*
The aim of this paper is to examine interorganisational co-operation in view of the theory of organisational entrepreneurship. The fundamental question behind the paper is whether collaboration could be perceived as entrepreneurial behaviour and, furthermore, whether opportunities could be pursued through collaboration and creating new alliances. Such a thesis is confronted with competitive aggressiveness that is proposed as one of dimensions of entrepreneurial orientation. The concepts of collaborative entrepreneurship is described. Indications to include collaboration into the entrepreneurial theory are suggested, and some ideas of conceptualisation and operationalisation are discussed.
\end{abstract}

Keywords: entrepreneurship, collaboration, entrepreneurial orientation.

Submitted: 07.08.2016 | Accepted: 08.11.2016

\section{Współpraca międzyorganizacyjna w świetle teorii przedsiębiorczości}

Celem artykutu jest analiza wspótpracy międzyorganizacyjnej $w$ świetle teorii przedsiębiorczości organizacyjnej. Podstawowe pytanie, na które staramy sie odpowiedzieć w artykule brzmi: czy wspótpraca może być postrzegana jako zachowanie przedsiębiorcze, a w dalszej kolejności, czy można podażać za sposobnościami poprzez wspótpracę i tworzenie aliasów. Wyrażajaca to teza jest konfrontowana z konkurencyjną agresywnościa jako jednym z wymiarów orientacji przedsiębiorczej. Omówiona została koncepcja przedsiębiorczości bazującej na wspótpracy oraz przedstawiona propozycja wtaczenia wspótpracy do teorii przedsiębiorczości i poddane zostaty dyskusji odnoszace się do tego zalecenia dotyczace konceptualizacji i operacjonalizacji.

Słowa kluczowe: przedsiębiorczość, współpraca, orientacja przedsiębiorcza.

Nadesłany: 07.08.2016 | Zaakceptowany do druku: 08.11.2016

JEL: L26, L31, L39

Rafal Kusa, PhD - AGH University of Science and Technology in Kraków, Faculty of Management, Department of Organisational Management, Human Resources Management and Economic Law. Mailing address: AGH University of Science and Technology in Kraków, Faculty of Management, Department of Organisational Management, Human Resources Management and Economic Law; e-mail: rkusa@zarz.agh.edu.pl. 


\section{Introduction}

One of the behaviours observed among organisations is collaboration. Some of them build their strategy on co-operation, while others combine co-operation with competition (which is called co-opetition). Interorganisational co-operation offers access to resources and markets that are not available for single organisations. Thus, interorganisational co-operation may be perceived as a way of surviving and developing in a competitive environment.

The other important trait of the environment is variability. The changing surroundings offer many opportunities (as well as threats). Many organisations strive to benefit from such conditions through pursuing these opportunities. Such an attitude is identified with entrepreneurship (Stevenson and Jarillo, 1990). The different attributes have been exposed alongside the evolution of entrepreneurship theory. Today, most academics agree that the main dimensions of entrepreneurial attitude are risk-taking, pro-activeness, and innovativeness. However, some of them also add autonomy and competitive aggressiveness to this list.

The question behind the paper is whether collaboration may be treated as an attribute of entrepreneurship and a way of pursuing entrepreneurial opportunities. In this paper, we will focus on the organisational level in an attempt to answer the following question: Is interorganisational collaboration an attribute of the entrepreneurship of an organisation? Such a question arises both from theory (may entrepreneurial opportunities be pursued through collaboration?) and practice (are those entrepreneurs who collaborate more or less entrepreneurial and effective?). Such a question stays in opposition to the mainstream of discussions about entrepreneurship, wherein the entrepreneurs are presented as individual heroes who value their autonomy and behave aggressively towards their competitors. Some concepts suggest that the more aggressive behaviours are displayed, the more entrepreneurial an organisation is. However, "working alone" was not widely accepted as the constituent attribute of entrepreneurship, and identifying it with individuals is even presented as one of the myths regarding entrepreneurship (Morris, 1998).
The aim of this paper is to identify the links between entrepreneurship and collaboration in an organisation as well as to propose the operationalisation of relationships between them. The aim is connected with the process of building a research tool for the measurement and comparison of an entrepreneurial orientation of for-profit and non-profit organisations. The paper is a conceptual one. The literature study is used as a dominant research method. However, our literature review is focused on the few publications that link collaboration and entrepreneurship. In the areas of interorganisational collaboration and the general theory of organisational entrepreneurship, only the most influential works are employed. The structure of the paper is as follows. Firstly, interorganisational collaboration is presented. Then, organisational entrepreneurship (understood as pursuing entrepreneurial opportunities) is described with a special focus on its conceptual connection with collaboration. Then, collaboration is related to an entrepreneurial orientation and its selected dimensions. Several research propositions are suggested throughout the paper; however, some of them are not revealing, and their role is to structure the reasoning. These are discussed, and recommendations for future research are suggested afterwards.

\section{Interorganisational Collaboration}

Collaboration is one of the types of relationships between organisations. It is defined as "a process in which autonomous actors interact through formal and informal negotiation, jointly creating rules and structures governing their relationships and ways to act or decide on the issues that brought them together" (Thomson and Perry, 2006, p. 23). Collaboration occurs "when a group of autonomous stakeholders of a problem domain engage in an interactive process, using shared rules, norms, and structures, to act or decide on issues related to that domain" (Wood and Gray, 1991, p. 146).

Collaboration is perceived as a much more complex and demanding process than co-operation, where desired outcomes are relatively clear and the distribution of future returns can be negotiated (Miles et al., 2006). Thomson and Perry (2006, p. 23) posit that "cooperation and 
collaboration differ in terms of their depth of interaction, integration, commitment, and complexity, with cooperation falling at the low end of the continuum and collaboration at the high end". According to Gray (1989), co-operation (similarly to coordination) may occur as a part of the early process of collaboration (Thomson and Perry, 2006). In the paper, both terms (collaboration and co-operation) are used interchangeably; however, collaboration is better suited to a complex activity such as entrepreneurship.

Interorganisational collaboration occurs in vertical or horizontal forms. Vertical alliances are identified throughout the value chain, with upstream and downstream partners (Spence et al., 2008). Organisations that belong in a supply chain strive to deliver value to the end-consumer as well as to maximise profitability for all of its members. In the supply chain context, collaboration is defined as "the ability to work across organisational boundaries to build and manage unique value-added processes to better meet customer needs. It goes beyond managing transactions for efficiency to managing relationships for creativity and continuous improvement" (Fawcett et al., 2008, p. 93). The development of long-term relationships among the companies of a supply chain is a condition of the reduction of uncertainty and, therefore, a source of conflict, making the supply chain more competitive (Ernst et al., 2009).

Horizontal alliances are based on collaboration with firms across industries, and they even involve relationships with competitors. Cross-industry collaborative ventures involve firms from unrelated sectors that pool non-substitutable resources, which leads to symbiosis; while, through collaboration with competitors, two or more competitors pool their resources on specific projects and continue to compete with others (Spence et al., 2008).

Organisations get involved in collaborative relationships with each other for varied reasons. They include lower transaction costs, synergistic effects, reduction of competitive risks, enhanced offers to customers, better customer retention due to higher switching costs, and overcoming operational weaknesses (e.g. in the supply chain); however, the primary motive is often the search for complementari- ties (Spence et al., 2008). Dyer and Singh (1998) suggest that interfirm linkages may be a source of relational rents and competitive advantage. From the perspective of resource-based theories, an important motivation to collaborate is overcoming limits in one's access to resources. Thus, collaboration may be especially attractive for small and medium-sized enterprises (SMEs) that often face such problems. Moreover, relational capital may be a fundamental asset for SMEs (Welbourne and Pardo, 2009).

Collaboration is perceived as one of the accelerators of innovativeness. Along with product development and related R\&D, innovation implementation is a common motive for collaboration. There is substantial empirical evidence that proves the significance of a relationship between interorganisational collaboration and innovativeness. Alexiev et al. (2016, p. 981) perceive interorganisational collaboration as "an important intervening mechanism between managers' concerns about their organization's environment and firm innovativeness". Their findings show that, when firms used interorganisational collaboration in their innovation process, they excelled at firm innovativeness as well. Results of the research on collaborations suggest that the impact of different forms of collaborative innovation may vary depending on the stage of the innovation process. For example, Walsh et al. (2016) have found that vertical collaboration at the inventing stage is relatively more critical to commercialisation than university-industry collaboration. However, multiparty collaboration creates significant barriers to success, including higher coordination costs, communication barriers (distance and cultural barriers, lack of shared understanding), and disagreements over invention and innovation strategy (Walsh et al., 2016).

Interorganisational collaboration may involve many organisations of different types, including enterprises, their suppliers, and other institutions operating in a particular field. An example of the local structures wherein such collaboration occurs is an industry cluster as conceptually developed by Porter (1990). The connection between collaboration and innovative activity of organisations is also reflected in the concepts of open innovations as well as knowledge management. 
The effectiveness of interorganisational collaborations is determined by numerous factors. Townsend proposed that the success of collaboration is a function of the choice of appropriate partner(s), the management of the partner relationship, and the accumulation of relational capital (Yao et al., 2009). Collaboration relies heavily on trust and a joint commitment to the values of honesty and equitable treatment (Miles et al., 2006). Some other factors may influence the collaborative activity of an organisation as well, e.g. personal attitude towards co-operation or organisational and personal experience. Also, organisational culture, especially its dimension connected with attitudes towards the external environment, may determine the collaborative activity. Klimas (2014) indicated political and legal factors, interpersonal relationships, and time consumption as barriers that impede the creation of interorganisational relationships. Lisowska (2016) pointed out some barriers for co-operation development between enterprises and business environment institutions, i.e. the low propensity for co-operation, lack of funding for co-financing projects, lack of knowledge about the possibilities of co-operation, lack of innovation and lack of willingness to make changes, inability to see the purpose and benefits of co-operation, and lack of qualified staff.

In the following part of the paper, we deliberate whether interorganisational collaboration is associated with the entrepreneurial approach to an organisation.

\section{Entrepreneurship \\ and Collaboration in Pursuing Opportunities}

Entrepreneurship is defined by Stevenson and Jarillo (1990, p. 23) as "a process by which individuals - either on their own or inside organisations - pursue opportunities without regard to the resources they currently control". Shane and Venkatraman (2000, p. 218) also refer to opportunities in their definition of entrepreneurship as "scholarly examination of how, by whom, and with what effects opportunities to create future goods and services are discovered, evaluated and exploited". McGrath and MacMillan posit that "entrepreneurship is about the relentless pursuit of opportunities as well as resources" (Ma and Tan, 2006, p. 714). Morris (1998, p. 8) states that entrepreneurship "starts with an opportunity, and opportunities are rooted in the external environment". Eckhardt and Shane (2003, p. 336) propose that entrepreneurial opportunities are "situations in which new goods, services, raw materials, markets, and organising methods can be introduced through the formation of new means, ends, or means-ends relationships". The definitions above show that organisational entrepreneurship is identified with activities related to opportunities.

Management theory shows numerous reasons and benefits resulting from co-operation (which were presented previously). Co-operation with another organisation is related to the external environment, and it is a situation that may yield new market solutions. Moreover, some of these solutions would never arise without co-operation. Therefore, interorganisational collaboration may be perceived per se as an opportunity. This is in line with Zur (2015), who considers subcontracting as the potential entrepreneurial opportunities of both subcontracting firms and their subcontractors. Such a perception is also relevant to other types of interorganisational collaboration as well as to the availability of potential business partners. Taking the above opinions into consideration, the following proposition is suggested:

Proposition 1: Co-operation may be considered as an opportunity.

Gulati (1998, p. 294) observed that "many new opportunities for alliances were presented to firms through their existing sets of alliance partners".

Entrepreneurship is identified with creating organisations (Shook et al., 2003). Gartner (1989, p. 47) states that "what differentiates entrepreneurs from nonentrepreneurs is that entrepreneurs create organizations, while non-entrepreneurs do not". New organisations may also be created within an existing organisation, which is perceived as one of the manifestations of corporate entrepreneurship (Sharma and Chrisman, 1999). The following question arises from such an understanding of entrepreneurship: Is the creation of collaborative forms of activity (in order to pursue an opportunity) an entrepreneurial behaviour? Such a question is crucial when an entrepreneur is not able to exploit the 
opportunity alone (e.g. because of insufficient resources available), and he/she has to find another way to pursue the opportunity than creating a new organisation alone. Examples of alternative options in such a case are the creation of a franchising network (by franchisors) or building a consortium (by a group of corporations). Franco and Haase (2013, p. 691) perceive the establishment of interfirm alliances as the way of "putting entrepreneurial activities into practice" (in the frame of collaborative entrepreneurship). Despite the differences between creating a new organisation and a new network or alliance, it may be posited that:

Proposition 2: Creating networks or alliances could be entrepreneurial acts.

Entrepreneurship is identified with autonomy and independence. Lumpkin and Dees (1996, p. 140) define autonomy as "the ability and will to be self-directed in the pursuit of opportunities". Results of the research show that the personal independence or self-fulfilment that comes with self-employment is one of the most important reasons why people would prefer to be self-employed (European Commission, 2012). This is in line with the image of an entrepreneur as an individual who alone revolutionises the marketplace.

However, more than half of American entrepreneurs share ownership in their business start-ups rather than going it alone (Ruef, 2010). Morris (1998, p. 5) posits that "entrepreneurship does not happen without teams", and Johannisson (2003) presents entrepreneurship as "a collective phenomenon that is as much the outcome of a joint effort as an individual endeavor" (Ribeiro-Soriano and Urbano, 2009, p. 422).

Collaboration is gaining the attention of researchers who are focused on organisational entrepreneurship. It is reflected in the concepts of collective and collaborative entrepreneurship. Ribeiro-Soriano and Urbano (2009) identify collaborative entrepreneurship with a company's ability to collaborate outside the organisation (while collective entrepreneurship is identified with the ability to collaborate within the organisation). They posit that collaboration enables a firm to be entrepreneurial and continuously innovative by exploring new markets. Gupta and Govindarajan (2000) state that "the concept of collabo- rative entrepreneurship is based on the creation of something of economic value arising out of new, jointly created ideas that emerge from the sharing of information and knowledge".

The preceding review shows that, despite widely accepted connotation between entrepreneurship and entrepreneurs' tendency to act independently, sharing the activity through collaborations is also considered in the context of entrepreneurship. This leads to the following proposition:

Proposition 3: Entrepreneurs may accept collaboration as a way of pursuing opportunity despite the limitation of their independence and autonomy.

The three propositions suggested previously are related to three key aspects of entrepreneurial activity: pursuing an opportunity, creating a new organisation, and autonomy. However, they can be considered from one more perspective: profit maximising - entrepreneurs strive not only to seize the opportunity but also to maximise gains from it. And collaboration may be, under some conditions, more efficient than pursuing the opportunity alone and, thus, may lead to higher profitability. Moreover, in the case of limited access to resources, collaboration may be the only way of seizing the opportunity. As stated previously, this could be the key motivation for SMEs, wherein a strong entrepreneurial approach is accompanied with limited access to resources.

\section{Collaboration and Entrepreneurial Orientation}

Miller (1983, p. 771) proposed that the entrepreneurial organisation is "one that engages in product-market innovation, undertakes somewhat risky ventures, and is first to come up with proactive innovations". Based on this definition, Lumpkin and Dess developed the concept of entrepreneurial orientation (EO), which is characterised by "a propensity to act autonomously, a willingness to innovate and take risks, and a tendency to be aggressive toward competitors and proactive relative to marketplace opportunities" (Lumpkin and Dess, 1996, p. 137). Anderson et al. (2015, p. 1583) proposed a different approach to EO as "a multidimensional construct consisting of two non-interchangeable 
dimensions - entrepreneurial behaviors and managerial attitude towards risk" where "both dimensions are fundamentally necessary for EO to exist". EO is the most utilised basis for measurement scales of organisational entrepreneurship. One such basis has been proposed by Hughes and Morgan. It consists of 18 items related to 5 dimensions: risk-taking, innovativeness, proactiveness, autonomy, and competitive aggressiveness, and 5 questions related to the business performance of the firm (Hughes and Morgan, 2007).

Traditionally, collaboration has not been perceived as a dimension of entrepreneurship and is not included in EO scales; however, Ribeiro-Soriano and Urbano (2009) posit that entrepreneurial organisations have the capacity to form collaborative relationships, and Franco and Haase (2013) state that firms are also considered entrepreneurial if they show themselves to be innovative and pro-active by forming co-operative relationships with external partners. Based on the above ideas (as well as Propositions 2 and 3), the following may be proposed:

Proposition 4: Collaboration may be perceived as one of the dimensions of entrepreneurial orientation and may be included in the scales of entrepreneurial orientation.

As one of the dimensions of EO, collaboration is interconnected with other EO dimensions: proactiveness, innovativeness, risk-taking, autonomy, and competitive aggressiveness.

Proactiveness refers to a firm's attitude towards market opportunities in the process of new entry, and particularly to "seizing initiative and acting opportunistically in order to 'shape the environment'; that is, to influence trends and, perhaps, even create demand" (Lumpkin and Dess, 1996, p. 147). Khan and Manopichetwattana (1989) have found that an abundance of resources (which is one of the reasons for collaboration) encourages proactiveness. Developing our Proposition 2, it may be assumed that proactiveness may also be exposed by collaborative initiatives; furthermore, it may be posited that collaborative activity supports proactivity. However, such a hypothesis requires empirical verification.

As stated earlier, collaboration is perceived as one of the determinants of organisational innovativeness. In the context of EO, Franco and Haase (2013) found that, for a firm's innovative capacity, there is a significantly positive impact on the alliance decision. It may be assumed that collaboration and innovativeness are positively correlated in an EO context.

The relationship between collaboration and risk-taking is an ambiguous one. Collaboration is perceived as a way of reducing risk (e.g. by sharing investments with partners), which could suggest that the higher the collaboration involvement, the lower the risk exposure. However, partners may be a source of uncertainty. As a consequence, the question arises: Is the level of entrepreneurship the same when an entrepreneur creates a new one-ownership enterprise and does so with business partners or as an alliance? Partnerships are often initiated in the face of challenging and promising opportunities (that are not achievable when acting alone because of insufficient resources available to an individual entrepreneur, for example), which requires each partner to take an outstanding risk. It is partly in line with the findings of Franco and Haase (2013) that a risk-taking tendency is negatively linked with the establishment of alliances (when the risk-taking propensity of the firms in their sample increases, the tendency to form alliances diminishes). The correlation between collaboration and risktaking requires further investigation.

Autonomy is perceived as "a key dimension of an entrepreneurial orientation" (Lumpkin and Dess, 1996, p. 140). Pursuing the opportunity by collaborating with partners requires negotiations and somehow limits the entrepreneur's self-direction. However, according to Proposition 3, entrepreneurs may accept the limitation of their independence and autonomy to strengthen their chance of seizing an opportunity. Autonomy refers to the independent action of an individual as well as a team. The members of the independent team may act autonomously, but they may co-operate with each other within the team. Such a co-operation is reflected in the concept of collective entrepreneurship, which refers to entrepreneurial teams and to collaboration among employees (Ribeiro-Soriano and Urbano, 2009). This suggests the following proposition reflecting the coexistence of collaboration and autonomous activity: 
Proposition 5: Collaboration and autonomous activity may occur in parallel within one organisation (at different levels of the organisational structure).

From the perspective of the main assumption of the paper, it is important that interorganisational co-operation may occur among organisations wherein autonomous entrepreneurs or entrepreneurial teams operate. However, it can be expected that the collaborative attitude exhibited by employees in relationships with their workmates may influence the organisational approach towards other organisations and a willingness to engage in interorganisational co-operation. The collaborative behaviours (considered at the same organisational level) are somehow in opposition to autonomy and independence, which leads to the assumption that there is an inverse monotonic relationship between collaboration and autonomy. Such a relationship implies challenges for the organisational culture and motivation system (which behaviours do we promote and prize?).

Finally, the fifth EO dimension is competitive aggressiveness. Lumpkin and Dess (1996, p. 148) characterise this as “a firm's propensity to directly and intensely challenge its competitors to achieve entry or improve position". Competitive aggressiveness towards competitors may be perceived as the opposite of co-operation. The question appears whether collaboration and competition could occur within one organisation simultaneously. The theories that combine both attitudes (as co-opetition) suggest that this is possible. Entrepreneurs may compete with some enterprises and collaborate with others at the same time. They may also change their attitudes and relationships with particular companies and may start to co-operate with companies with whom they used to compete if they assess that co-operation is profitable at a particular moment or in a particular case. According to Proposition 3, they may do so to pursue entrepreneurial opportunities, and sometimes (according to Proposition 1) they may perceive the possibility of co-operation as an opportunity per se. This suggests the following proposition:

Proposition 6: Entrepreneurs may co-operate instead of competing to pursue an opportunity.

Competitive aggressiveness may be reflected in such behaviours as head-to-head confrontation based on unconventional methods of competing (Lumpkin and Dess, 1996). Hughes and Morgan (2007, p. 659) included the following items relevant to competitive aggressiveness in their scale: 'Our business is intensely competitive'; 'In general, our business takes a bold or aggressive approach when competing'; 'We try to undo and out-manoeuvre the competition as best as we can'. Some scales consist of pairs of opposing statements. Lumpkin and Dess (2001, p. 451) use the following pair: 'In dealing with its competitors, my firm typically adopts a very competitive "undo-the-competitors" posture" with 'In dealing with its competitors, my firm typically seeks to avoid competitive clashes, preferring a "live-and-let-live" posture'. Following Proposition 6, some items related to interorganisational collaboration may be included in EO scales. They might sound like the following: 'Our business is intensively collaborative'; 'Our business takes an open approach towards competitors'; 'In dealing with its competitors, my firm typically seeks partners to build alliances, preferring a "win-win" strategy'; 'In dealing with other organisations that operate in our market, my firm typically seeks the possibilities to co-operate on pursuing opportunities or increasing access to resources by sharing them (or secure sufficient resources required to seize the opportunity)'.

According to a more quantitative approach to EO measurement, we can ask about the number of alliances or partnerships (beyond those in the frame of value chains) or the number of opportunities pursued in collaboration with the firm's "co-opetitors". If general ability to co-operate is treated as one of the entrepreneurial skills, it could be generally supposed that co-operation is also a kind of entrepreneurial behaviour. That is also relevant to co-operation with partners within the value chain. Thus, in some cases, it may be assumed that the more business partners and the closer relationships with them, the more entrepreneurial an organisation is.

Entrepreneurs may also simultaneously compete and co-operate (even with competitors). Entrepreneurs may compete collectively, which is one of the main issues in supply-chain management (Adams et al., 2014). In fact, entrepreneurs collaborate 
with business partners from their value chain more often than with their competitors. Such relationships may be also perceived as entrepreneurial behaviours: after all, they co-operate to increase their profit (through seizing together an entrepreneurial opportunity). They try, for example, to serve more clients as well as utilise more suppliers. The skills required to co-operate are perceived as important skills of every entrepreneur (Boyles, 2012). Therefore, collaboration may be considered in an entrepreneurial context not only in the associations with competitors (as opposed to 'competitive aggressiveness') but also with other organisations that may influence (positively or negatively) their seizure of the opportunity. Thus:

Proposition 7: Entrepreneurs may collaborate with different organisations, including business partners from the value chain as well as competitors.

The last four propositions imply the need to review EO scales and suggest their extension by including collaboration as one of the EO dimensions.

\section{Discussion}

The results of the analysis embodied in our submitted propositions show the multidimensional connections between interorganisational collaboration and organisational entrepreneurship. However, one question is still unanswered: Is interorganisational collaboration one of the dimensions that constitute entrepreneurship? The answer is not obvious.

Firstly, the concept of entrepreneurship has evolved over the time, and there is no widely accepted operationalisation of it (even if EO is dominant, it is not the only concept, and different constructs of EO are utilised). Moreover, the discussion on the definition of entrepreneurship is still ongoing. There are some propositions of a set of dimensions of organisational entrepreneurship, but the list of dimensions is still open to debate.

Secondly, organisational entrepreneurship is a multidimensional phenomenon, and organisations are requested to simultaneously exhibit sufficient levels of each dimension to be considered 'entrepreneurial'. This implies that none of the dimensions are the equivalent of entrepreneurship alone. Thus, to compete aggressively does not mean to be entrepreneurial if other dimensions do not emerge. The assumption that interorganisational collaboration is one of the dimensions of entrepreneurship implies that the organisation has to collaborate (exhibit a high level of interorganisational collaboration) to be classified as entrepreneurial. Such a statement may be questioned, depending on the assumed definition of organisational entrepreneurship. In the case of definitions focused on for-profit organisations, interorganisational collaboration as one of the entrepreneurial behaviours may be unacceptable, while in the case of definitions focused on entrepreneurship in a wider context (including social entrepreneurship), it may be an important trait, enabling us to distinguish organisations and their entrepreneurial capacity in terms of their goals, for example. However, if collaboration is to be approved as the universal dimension of entrepreneurship, it should be represented by all organisations, including for-profit ones (aspiring to be entrepreneurial, under such a definition). And as a consequence, those organisations that do not accomplish a requested minimum level of collaboration would not be recognised as 'entrepreneurial'. Such a rule may not be fully accepted today (neither in theory nor in practice).

Finally, it should be noted that collaboration (like other dimensions of organisational entrepreneurship) may occur at a different level of intensity. This suggests the following question: What level of collaboration is required to be considered significant in the context of an organisation's entrepreneurship? Such a question is also relevant to other dimensions as well as the total level of an organisation's entrepreneurship (or the level of an organisation's EO). And the answers may vary depending on the organisational context in which it occurred (Miller, 2011).

\section{Limitations and Recommendations}

The analysis here and its results have some limitations that offer possibilities for future research. First, the presented propositions are the results of literature studies in the fields of collaboration and entrepreneurship. The literature review has embraced only selected sources, while 
both fields are replete with numerous publications. However, the theoretical line combining both fields needs to be advanced, as the paper rather exhibits questions than offers answers or explanations. The analysis was conducted at the organisational level, but the relationship between collaboration and entrepreneurship may be analysed from a macro-level perspective to support the answer to the question about the impact of collaborative (versus competitive) behaviours of entrepreneurs on the economy.

Secondly, collaboration was analysed in the context of the main entrepreneurship theory (that is based on entrepreneurial opportunities), and its dominant operationalisation (i.e. entrepreneurial orientation). However, there are some other theories of organisational entrepreneurship that may be related to collaboration, and organisational entrepreneurship may occur in different types of organisations, including for-profit and non-profit ones. As social entrepreneurship is attracting an increasing number of researchers, interorganisational collaboration in a social entrepreneurship context is a promising field of research. Comparative research of traditional and social entrepreneurs is recommended to confront the role of collaboration in seizing opportunities in different types of organisations and identify its role in pursuing societal needs. Forthcoming theoretical studies might examine collaboration from the perspective of other entrepreneurial concepts as well (e.g. corporate, family, public, international entrepreneurship).

Thirdly, the limitations inherent in the method used in this paper suggest the implementation of other methods. The propositions presented in this paper may be developed into a research hypothesis and then verified through an empirical survey. However, this requires the operationalisation of the concept of organisational entrepreneurship to be modified (e.g. EO), and furthermore, new measurement instruments and scales to be employed. The scales of organisational entrepreneurship were originally designed for business organisations and exposed competition (including aggressiveness) while disregarding collaboration. Although they are statistically relevant, such scales may not be relevant to social entrepreneurs, while any new scales will require validation and testing.

Organisational entrepreneurship is a multidimensional phenomenon where its dimensions interact with each other. The scrutiny of such interdependencies (e.g. between interorganisational collaboration and competitive aggressiveness or attitude towards risk) is one of the research areas emerging as a consequence of including collaboration into the set of entrepreneurial dimensions. The next research field is a relationship between collaboration and performance in an entrepreneurial context, and EO (measured with scales that include collaboration) and performance.

There are also some questions about collaboration and entrepreneurship with practical significance arising from the analysis. They include the following: How is interorganisational collaboration utilised by entrepreneurs in pursuing entrepreneurial opportunities?; How is collaboration influenced by the type or scale of activity, the external environment, or some other factors?; How does the organisation's goal (e.g. profit maximising or addressing societal needs) determine the entrepreneur's choice between collaboration and competing?; What is the mechanism of keeping balance or switching between competitive and collaborative behaviours?; How can entrepreneurs be encouraged and trained to utilise collaboration with other organisations in pursuing opportunities?

\section{Conclusion}

This paper contributes to the theory of both organisational entrepreneurship and interorganisational collaboration. The results show that entrepreneurship may exhibit by collaboration (at least in some cases). Collaboration may be analysed as entrepreneurial activity, and pursuing opportunity may be one of the motives behind collaboration. These contributions may be useful for developing theoretical constructs and models. They also suggest new areas of research that have been described in the paper. They may be a basis for future recommendations for practitioners, showing that, under some circumstances, entrepreneurship may be more collaborating than competing. 
The results suggest that entrepreneurs are required to balance competitive and collaborative behaviours or to be able to choose and implement the most efficient type of relationship with other organisations according to the circumstances.

Among the many changes that have taken place since the modern theory of organisational entrepreneurship was proposed, at least two are related to the topic of the paper. Firstly, the organisations' environment has changed and new models of operating, based on the interorganisational relationships, have been disseminated. Secondly, entrepreneurship is applied not only to profit-generating activity but also to activities that are aimed at societal needs, where collaboration is more adequate than competing. These changes suggest the reflection on the place of collaboration in the concept of organisational entrepreneurship.

\section{References}

Adams, F.G., Richey Jr., R.G., Autry, C.W., Morgan, T.R. and Gabler, C.B. (2014). Supply chain collaboration, integration, and relational technology: How complex operant resources increase performance outcomes. Journal of Business Logistics, 35(4), 299-317, http://dx.doi.org/10.1111/jbl.12074.

Alexiev, A.S., Volberda, H.W. and Van den Bosch, F.A.J. (2016). Interorganizational collaboration and firm innovativeness: Unpacking the role of the organizational environment. Journal of Business Research, 69, 974-984, http://dx.doi.org/10.1016/j. jbusres.2015.09.002.

Boyles, T. (2012). 21st century knowledge, skills, and abilities and entrepreneurial competences: A model for undergraduate entrepreneurship education. Journal of Entrepreneurship Education, 15, $41-55$.

Dyer, J.H. and Singh, H. (1998). The relational view: Cooperative strategy and sources of interorganizational competitive advantage. Academy of Management Review, 23(4), 660-679.

Eckhardt, J. and Shane, S. (2003). Opportunities and entrepreneurship. Journal of Management, 29(3), 333-349.

Ernst, R., López-Sánchez, J.I. and Urbano, D (2009). A negotiation model for inducing higher service in a distribution channel. Group Decision Negotiation, 18(5), 499-517.

European Commission. (2012). Entrepreneurship in the EU and beyond. Flash Eurobarometer (354). Retrieved from http://ec.europa.eu/public_opinion/ flash/fl_354_en.pdf.
Fawcett, S.E., Magnan, G.M. and McCarter, M.W. (2008). A three-stage implementation model for supply chain collaboration. Journal of Business Logistics, 29(1), 93-112.

Franco, M. and Haase, H. (2013). Firm resources and entrepreneurial orientation as determinants for collaborative entrepreneurship. Management Decision, 51(3), 680-696.

Gartner, W.B. (1989). "Who is an entrepreneur?" is the wrong question. Entrepreneurship Theory and Practice, Summer, 47-67.

Gulati, R. (1998). Alliances and networks. Strategic Management Journal, 19, 293-317.

Gupta, A.K. and Govindarajan, V. (2000). Knowledge flows within multinational corporations. Strategic Management Journal, 21(4), 481-510.

Khan, A.M. and Manopichetwattana, V. (1989). Innovative and noninnovative small firms: Types and characteristics. Management Science, 35(5), 597-606.

Klimas, P. (2014). Przesłanki i bariery zawiązywania więzi międzyorganizacyjnych. Problemy Zarzadzania, 13, 1(50), part 1, 29-46, http://dx.doi. org/10.7172/1644-9584.502.

Lisowska, R. (2016). The potential of business environment institutions and the support for the development of small and medium-sized enterprises. Entrepreneurial Business and Economics Review, 4(3), 85-101, http://dx.doi.org/10.15678/ EBER.2016.040307.

Lumpkin, G.T. and Dess, G.G. (1996). Clarifying the entrepreneurial orientation construct and linking it to performance. Academy of Management Review, 21, 135-172.

Lumpkin, G.T. and Dess, G.G. (2001). Linking two dimensions of entrepreneurial orientation to business performance: The moderating role of environment and industry life cycle. Journal of Business Venturing, 16, 429-451.

Ma, H. and Tan, J. (2006). Key components and implications of entrepreneurship: A 4-P framework. Journal of Business Venturing, 21, 704-725.

Miles, R.E., Miles, G. and Snow, C.C. (2006). Collaborative entrepreneurship: A business model for continuous innovation. Organizational Dynamics, 35(1), 1-11, http://dx.doi.org/10.1016/j.orgdyn.2005.12.004.

Miller, D. (1983). The correlates of entrepreneurship in three types of firms. Management Science, 29(7), 770-791.

Miller, D. (2011). Miller (1983) revisited: A reflection on EO research and some suggestions for the future. Entrepreneurship Theory and Practice, 35, 873-894, http://dx.doi.org/10.1111/j.15406520.2011.00457.x. 
Morris, M.H. (1998). Entrepreneurial intensity: Sustainable advantages for individuals, organizations, and societies. Westport-London: Quorum Books.

Porter, M.E. (1990). The competitive advantage of nations. New York: The Free Press.

Ribeiro-Soriano, D. and Urbano, D. (2009). Overview of collaborative entrepreneurship: An integrated approach between business decisions and negotiations. Group Decision Negotiation, 18, 419-430.

Ruef, M. (2010). The entrepreneurial group: Social identities, relations, and collective action (In The Kauffman Foundation Series on Innovation and Entrepreneurship). Princeton: Princeton University Press.

Shane, S. and Venkatraman, S. (2000). The promise of entrepreneurship as a field of research. Academy of Management Review, 25, 217-226.

Sharma, P. and Chrisman, J.J. (1999). Toward a reconciliation of the definitional issues in the field of corporate entrepreneurship. Entrepreneurship Theory and Practice, 23(3), 11-28.

Shook, C.L., Priem, R.L. and McGee, J.E. (2003) Venture creation and the enterprising individual A review and synthesis. Journal of Management, 29(3), 379-399.

Spence, M., Manning, L. and Crick, D. (2008) An investigation into the use of collaborative ventures in the internationalization of high performing Canadian SMEs. European Management Journal, 26(6), 412-428, http://dx.doi.org/10.1016/j. emj.2008.09.006.
Stevenson, H.H. and Jarillo, J.C. (1990). A Paradigm of entrepreneurship: entrepreneurial management. Strategic Management Journal, 11(4), 17-27.

Thomson, A.M. and Perry, J.L. (2006). Collaboration processes: Inside the black box. Public Administration Review, 66, Issue Supplement 1, 20-32, http://dx.doi.org/10.1111/j.1540-6210.2006.00663.x.

Walsh, J.P., Lee, Y.-N. and Nagaoka, S. (2016) Openness and innovation in the US: Collaboration form, idea generation and implementation. Research Policy, 45(8), 1660-1671, http://dx.doi. org/10.1016/j.respol.2016.04.013.

Welbourne, T.M., Pardo-del-Val, M. (2009). Relational Capital: Strategic Advantage for small and medium-size enterprises (SMEs) through negotiation and collaboration. Group Decision Negotiation, 18(5), 483-497.

Wood, D. and Gray, B. (1991). Toward a comprehensive theory of collaboration. Journal of Applied Behavioral Science, 27(2), 139-162.

Yao, X., Wen, W. and Ren, Z. (2009). Corporate entrepreneurship in the enterprise clusters environment - Influence of network resources and entrepreneurial orientation on firm performance. Frontiers of Business Research in China, 3(4), 566-582, http://dx.doi.org/10.1007/s11782-009-0027-x.

Żur, A. (2015). Subcontracting as entrepreneurial opportunity. Conceptualization and research model proposition. Studies of the Industrial Geography Commission of the Polish Geographical Society, 29(4), 54-67, http://prace-kgp.up.krakow.pl/article/ view/2994/2650 